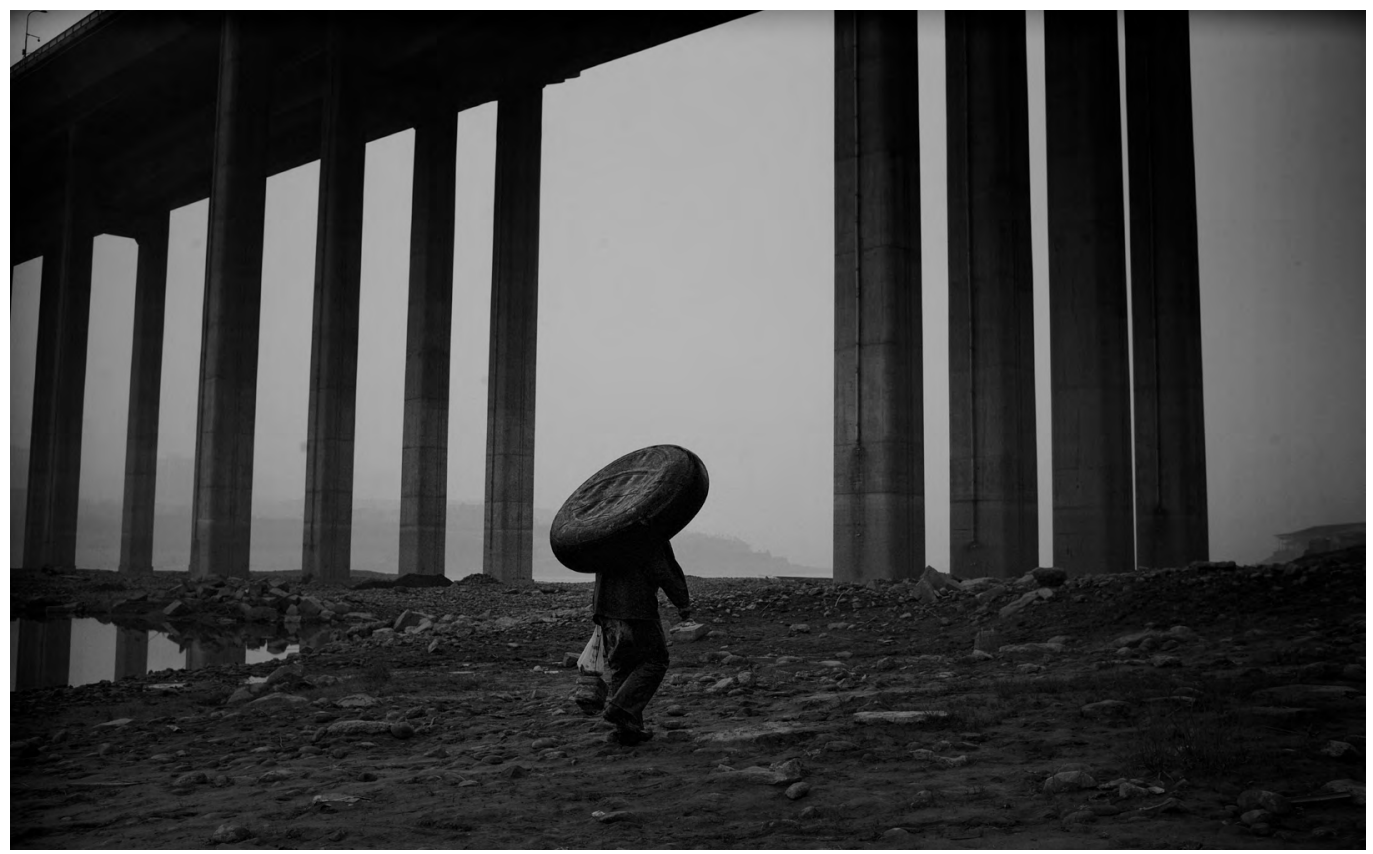

\title{
The Chongqing Model One Decade On
}

Chongqing.

PC: Jonathan van Smit.

\section{Yueran ZHANG}

One decade ago, Bo Xilai's 'Chongqing Model' was making headlines. Liberal commentators generally saw it as an expansion of authoritarian state power, while many on the left welcomed it as a counterpoint to China's capitalist turn. This essay examines what the model was really about, what it said more broadly about contemporary Chinese politics, and its afterlives under $X i$ Jinping.

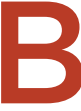
etween 2007 and 2012, China observers around the world and a significant segment of the international left paid a great deal of attention to a city in China's southwest, Chongqing. Under the leadership of the municipal secretary of the Chinese Communist Party (CCP), Bo Xilai, Chongqing's municipal government engaged in a set of extraordinary political practices, commonly known as the 'Chongqing Model' (重庆模式). It promoted a strong ideological message centred on 'common, shared prosperity' (共同富裕) and economic egalitarianism, and crafted policies that allegedly served redistributive purposes. It launched the high-profile 'Striking Black' (打黑) campaign to prosecute Bo's political 
rivals and the city's entrenched wealthy elite in the name of cracking down on 'black' gangsters. It regularly organised, or encouraged people to self-organise, large public assemblies in which thousands gathered to sing classic 'red' songs of the Maoist era. It also displayed extreme intolerance towards those who criticised the state, sending some to labour camps.

Liberal commentators generally saw the Chongqing Model as an appalling expansion of the coercive abuse of authoritarian state power. Many on the left, in contrast, welcomed the model as a much-needed counterpoint to China's capitalistic turn in the reform era and the beginning of a more just and equitable mode of development. While the debate about how to make sense of the Chongqing Model became increasingly divisive, the model itself suddenly collapsed in 2012 in a series of sensational political scandals. Wang Lijun, a close associate of Bo, defected to the US Consulate in February that year after falling out with him. This led to the public revelation of the murder of a British businessman by Bo's wife. Bo was subsequently removed from office in March 2012 and eventually sentenced to life imprisonment on corruption charges.

Despite the significant attention garnered by the Chongqing Model during its unfolding and the dramatic manner in which it ended, serious reflections and re-examinations of the model have been lacking since 2012. What was the model about? Should we take the liberal and left narratives at face value? What did the model say about the broader picture of contemporary Chinese politics? Was there any connection between the Chongqing Model and China's post-2012 political transformations under President Xi Jinping? These questions have rarely been posed by China observers, which reflects an underestimation of the Chongqing Model's political substance and import.

A research project I have conducted over the past few years allowed me to formulate some tentative answers to these questions. Even though the initial research question had nothing to do with the Chongqing Model, the project ended up providing a crucial window through which we could look at the model in a detailed and comparative manner. In this piece, I draw on my research findings to discuss how we could rethink the Chongqing Model's political nature and its legacies for China's post-2012 political transformations.

\section{Contrasting Modes of Taxation}

In 2016, I set out to research China's politics of taxing private homeownership. Whereas a nationwide wealth tax on private homeownership has yet to be instituted, Chongqing and Shanghai launched a policy experiment to tax private homeownership starting from 28 January 2011. Official propaganda and media pundits tended to describe the experiments in the two cities as part of the same policy package. However, after analysing policy documents and looking at how the taxes were collected on the ground, I uncovered striking differences in the ways in which the two governments framed, designed, and enacted their tax.

First, Chongqing's officials explicitly framed their tax on private homeownership as an antirich redistributive measure. In April 2010, Huang Qifan, Chongqing's mayor, appeared in an interview to flesh out the rationale for and vision behind the tax. Speaking on behalf of the government, he stated that "we will create zero tax burden on the poor ... provide tax breaks for the middle class ... and tax harshly the rich' (Huang 2010). This message was repeated in numerous official communications, tying the tax to an overall project of achieving common prosperity and equalising wealth distribution.

In contrast, Shanghai officials framed their tax as an emergency technical measure to solve the problems of an overheated housing market. The municipal government explained the tax as a way to adjust supply and demand and curb housing speculation, and always 
discussed the tax together with other technical interventions in the housing market, such as limits on property purchases and mortgages. To reinforce this message, the municipal government put the Municipal Housing Security and Administration Bureau, rather than the financial and taxation bureaus that conventionally oversee tax policy, in charge of designing the tax.

Stark differences also surfaced in how the two municipal governments defined their taxpayers. While Chongqing imposed its tax on all existing privately owned luxury property, Shanghai devised a forward-looking, "cut-off date' design: only if a Shanghai homeowner purchased a second property after the date on which the tax was enacted would they be required to pay an annual tax on the second property. Effectively, Chongqing's tax targeted the richest in the city. An official in one of Chongqing's local taxation bureaus halfjokingly said to me during an interview in 2017: 'In Chongqing, whether you are rich is determined by whether you pay this tax.' In contrast, Shanghai's tax spared the richest and instead focused on the somewhat less-rich households that were still affluent enough to purchase a second property after enactment of the tax: the moderately affluent stratum among middle-class households.

The actual enactment of the taxes presented even more dramatic points of divergence. Chongqing's municipal leadership instructed local taxation bureaus to devote a vast amount of resources and personnel to collecting its new tax, which severely impeded the collection of other taxes. Indeed, three policy researchers whom I interviewed separately in 2017 estimated that the negligible amount of money actually collected on the tax would not exceed the amount of resources devoted to collecting it. From the perspective of a costbenefit analysis, devoting so many resources to collecting one tax did not make sense. However, Chongqing's local taxation officials told me that the point was not how much money was actually collected, but to make the collection process as publicly visible as possible, to ensure that ordinary citizens could see that 'the government was on their side'.

Consistent with this logic, the state used publicly visible and confrontational methods to collect the tax, such as having official vehicles drive around rich neighbourhoods to process payments onsite and sending teams to intercept taxpayers at the airport. According to a researcher at the Chinese Academy of Social Sciences whom I interviewed in 2017, the tax officials would display large and visible banners, such as 'Taxpayers, welcome back!', when intercepting people at the airport. During such operations, the tax officials proactively interacted with bystanders and even invited ordinary people to join them. In November 2011, the state made a move that was highly unusual among China's tax collection practices at that time: it publicised the information of the 13 property owners who had not paid their tax on time. By announcing this information to the public, the state effectively called on the masses to participate in shaming and surveilling these people, who were portrayed as enemies. In other words, Chongqing's municipal government constituted the collection of this tax as a crucial rallying point for mass mobilisation.

In contrast, the Shanghai government took great care to get potential taxpayers to perceive the tax as an economic constraint, which was to be coped with by making calculated, strategic decisions privately and individually. The "cut-off date' design had a clear individualising effect. For those moderately affluent households that were planning to buy a second property, their reaction on hearing about the tax would be to rethink their purchasing plan and make the most economically sensible decision given this new parameter. The technical framing of the tax also made it intuitive for those moderately affluent households considering the purchase of a second property to imagine they might actually benefit from the tax because it was supposed to help tame the housing boom and make property cheaper. 
The differences between Chongqing's and Shanghai's modes of taxing private homeownership were highly systematic. Chongqing's municipal government embedded its tax in an ideological message of economic egalitarianism and utilised the tax as a means to mobilise the masses and build popular support for the state. Shanghai's municipal government, on the other hand, did everything it could to frame its tax as an economic and technical, rather than political, matter and to ensure that potential taxpayers responded to the tax in economic and individual, rather than political, ways. Underlying the contrasting modes of taxation, therefore, were two different political logics, which hold important implications for understanding the Chongqing Model.

\section{The Chongqing Model Reconsidered}

The 2011 tax experiments in Chongqing and Shanghai were not engineered by the central government. In late 2009, Chongqing's municipal government proposed to the central government, without prompting, that it would like to experiment with taxing private homeownership. The Chongqing officials who reached out to the central ministries explicitly conveyed the fact that Bo was behind the initiative, according to an informant I interviewed. This suggests that Chongqing's municipal leadership envisioned the tax as part of the unfolding Chongqing Model. Therefore, it is crucial to ask: what does the tax tell us about the political nature of the Chongqing Model more broadly?

Taking the tax experiment seriously leads me to doubt both the liberal and the left narratives. If we follow liberal commentators in understanding the Chongqing Model as an expansion of coercive and authoritarian state power, the tax experiment itself-never mind the manner in which it was adopted-makes little sense. Furthermore, the liberal emphasis on the model's coercive and authoritarian face cannot explain how it managed to consolidate a considerable amount of popular support in Chongqing. In fact, multiple international media outlets, including The Washington Post, the $B B C$, and Reuters, have reported anecdotal evidence that Bo's popularity among the masses remained very strong even after he was removed from office in 2012 and sentenced to life imprisonment on corruption charges (Richburg 2012; Grammaticas 2013; Wen 2017).

The left narrative, on the other hand, depicts the Chongqing Model as a substantial endeavour to address widening economic inequality through redistribution and explore a broadbased, pro-poor developmental path. However, if what happened with the tax on private homeownership is any guide, the actual degree of economic redistribution achieved under the Chongqing Model was extremely questionable, even though the discourse of egalitarianism played a prominent role. The primary concern for Chongqing's municipal leadership, it seems, was not how much material difference could be made to reduce economic inequality, but the political and symbolic effects of purported inequality-reducing, pro-poor measures.

I therefore argue that we should understand the Chongqing Model first and foremost as a project of mass political mobilisation that drew the masses into believing an ideological vision that identified the municipal government, and especially a charismatic state leader, as the champion of the people. This sense of collective identity between the people and the state was developed as the masses were mobilised to actively participate in various political activities. These were, of course, mostly orchestrated by the state, but within certain limits there was also some room left for spontaneous organisation.

Behind the emphasis on mass mobilisation and political participation was the subtle understanding that neither state coercion nor policies that led to material betterment would be enough to cultivate long-lasting political identification between the people and the state; instead, such identification could only be built when the masses themselves participated 


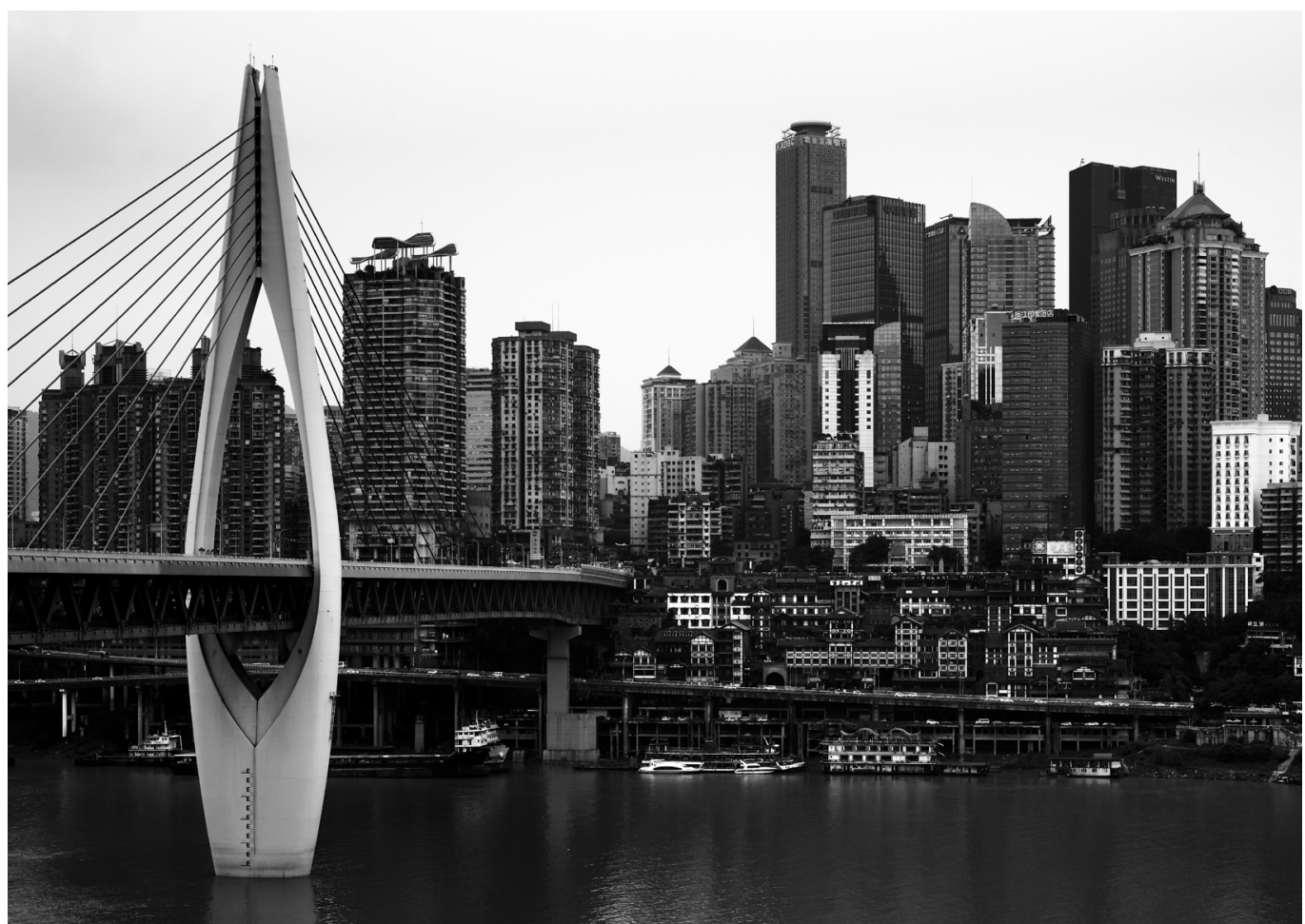

Chongqing, Dongshuimen Bridge. PC: Ivan G Shevchenko.

in politics. In other words, through mobilised participation, the Chongqing Model sought to reshape citizens into political subjects who identified with the state.

Public assemblies to sing 'red' songs, therefore, should be understood as a form of mobilised participation. It does not really matter whether those who were mobilised to participate in the assemblies did so voluntarily (many did not). As long as they were mobilised to participate, they became part of the largescale political spectacle professing support for the state, and the very experience of participating in such a massive spectacle was itself instrumental in cultivating a sense of political identity and loyalty (Wedeen 1999). Moreover, Chongqing's municipal government took great effort to fuse political spectacle with everyday life, encouraging people to 'sing red songs, read red classics, tell revolutionary and uplifting stories, and text exhortative maxims' in their daily lives (Zhao 2012). In a sense, political participation became indistinguishable from everyday routines, quietly and subtly contributing to the construction of new political subjects.

Similarly, the 'Striking Black' campaign utilised state violence as a means for mass mobilisation. In a signature victory of the campaign, a Chongqing court sentenced to death the city's former police chief, who was convicted of being a 'protection umbrella' for various crime groups. Shortly after his execution, many people put up street banners or lit firecrackers in celebration. It is unclear whether Chongqing's residents organised such actions on their own or were instructed by the state to do so, but it is clear that the 'Striking 
Black' campaign was very much intertwined with an effort to mobilise the masses to publicly identify with the state as the champion of the people against 'corrupt' elites. At the same time, Chongqing's municipal government encouraged the general public to report to the state any criminal activity (Cabestan 2011; Huang 2011), emphasising that social participation was indispensable to the success of the 'Striking Black' campaign.

The Chongqing Model even encouraged the masses to collectively participate in noninstitutional political actions. In November 2008, thousands of taxi drivers went on strike to protest excessive fines, insufficient fuel supplies, and a low pay schedule. In a highly unusual move, Bo started to coordinate different municipal agencies and taxi companies to address the strikers' concerns immediately after the strike started. Two days after the strike, Bo held a highly publicised and televised roundtable dialogue with strikers during which he acknowledged that they 'had reasonable discontent' and the government 'should first of all examine and reflect on what we have done wrong'. In stark contrast to the Chinese Government's usual approach to handling protest and contention, Bo openly endorsed the legitimacy of mass collective action and signalled that the state would be willing to take seriously the sentiments expressed through such action. This gesture effectively redefined collective action as no longer something that challenged or opposed the state, but as a form of political participation that connected the grassroots to the state.

Chongqing's ideological message of 'common, shared prosperity' and economic egalitarianism should thus be understood as part of this broader project of mass mobilisation, rather than in its own right. Putting forward an ideological vision in which Chongqing's middle and low-income sectors saw the state as their champion made the stateled mass mobilisation all the more effective, as political participation was rendered more appealing. The same logic also applied to redistributive economic policies, such as the tax on private homeownership. These policies provided opportunities for the state to present itself as the champion of the people and encourage further mass political participation; whether they actually redistributed wealth was not much of a concern.

In sum, the mobilisation of mass political participation was at the heart of the Chongqing Model-a project to cultivate long-lasting popular support for the municipal government and its leader, Bo Xilai. A variety of concrete mobilisation techniques (many of which were, of course, reminiscent of those widely used in the Maoist era), an ideological message, redistributive policies, and the exercise of state violence were all constitutive elements of this project. This model formed a sharp contrast with Shanghai's governing style, as seen through the handling of its tax on private homeownership: the state doing everything it could to make its policies appear apolitical and technocratic, while encouraging ordinary citizens to think and act in apolitical ways.

\section{The Landscape of High-Level Political Competition}

Many commentators have characterised the Chongqing Model as Bo Xilai's attempt to strengthen his position in the political competition for China's highest political office-more specifically, membership of the CCP's Politburo Standing Committee-in the 2012 leadership turnover (for example, Zhao 2012). However, it is not obvious why Bo would resort to mass mobilisation; after all, leadership competition in post-Mao China did not have a visible relationship with popular sentiment. Therefore, it is puzzling why Bo would take the trouble to launch an all-out mass-mobilisation project if he was serious about competing in China's elite politics. 
My research provided some clues to this puzzle. A retired official from the State Administration of Taxation whom I interviewed recounted what happened when Chongqing officials reached out to the central fiscal ministries about their proposal to tax private homeownership:

\begin{abstract}
When Chongqing's top leadership reached out to us saying they were planning to experiment with the tax, the Ministry of Finance officials were very happy; we were very happy, too. We wanted to help Chongqing to make this happen ... But at the same time, we were really concerned that, given the fact that Bo had so many enemies within the central leadership, the central leadership might not approve of this plan. Chongqing's people said Bo was also concerned about this, and this was why they worked so hard in the previous two years to rally lots of support from every corner of the society. If the central leadership did not approve, Bo was ready to use this support to put pressure on them. They said that in the hypothetical worst-case scenario, if the central leadership did not want to approve, they could just announce the plan to the public and demonstrate how popular it would be, so that the central leadership would have no choice but to approve.
\end{abstract}

And this is basically what happened: the Chongqing Government publicly announced the initiative and rallied popular support around it long before receiving approval from the central leadership.

What this suggests is that Bo's resorting to mass mobilisation should be understood as a response to his marginalised position in China's high-level politics or the fact that he 'had so many enemies'. In the major cycle of leadership turnover in 2007 , Bo, then the minister of commerce, was assigned to the post of Chongqing's CCP secretary rather than promoted to a higher position within the central government. Multiple media sources, as well as a US State Department cable obtained by WikiLeaks, suggest this assignment was a deliberate move by some top national leaders, such as then premier Wen Jiabao and vice-premier $\mathrm{Wu} \mathrm{Yi}$, to thwart Bo's political ambition and marginalise him politically. What is significant about this is not only the job assignment itself, which amounted to a demotion, but also the fact that some of the top national leaders were vehemently against Bo. Therefore, it makes sense to see Chongqing's mass-mobilisation efforts as an extraordinary yet desperate move by a marginalised politician. Rallying grassroots support was a way for Bo to counter and pressure those forces opposed to him within the political establishment. Riding on popular momentum to disrupt the political establishment's conventional rules of the game represented Bo's attempt to find a path forward in a political competition that was stacked against him.

Bo's employment of the mass-mobilisation strategy did make other competitors nervous, including those who had occupied more advantageous positions, such as $\mathrm{Yu}$ Zhengsheng, then Shanghai's municipal CCP secretary. In 1997, Yu was promoted directly from a prefecture-level leadership position in Shandong Province to a ministerial post in the central government-a highly unusual promotion. Four years later, he was promoted further to become the Party secretary of Hubei Province and appointed a member of the CCP's Politburo. At that time, it was rare for a firsttime Party secretary of an inland province to be appointed to the Politburo. On top of these two extraordinary promotions, in 2007, Yu was assigned to be Shanghai's Party secretary. This was widely seen as another significant promotion, signalling a high probability that he would enter the Politburo's Standing Committee in the next turnover.

However, according to officials in the central fiscal ministries who interacted with Shanghai's leadership at that time, Yu paid close attention to, and felt somewhat 
threatened by, Chongqing's moves as the Chongqing Model unfolded. The central fiscal ministries strategically exploited this anxiety to encourage Shanghai to launch its own tax experiment alongside Chongqing's. Therefore, the tax experiment there represented a reactive move by the Shanghai leadership to steal Chongqing's thunder.

For Shanghai, a reactive position did pose constraints. As Chongqing had already finished designing most of the specifics by the time it proposed its plan to the central government, Shanghai was under tremendous pressure to design a tax as quickly as possible and launch it at the same time as Chongqing. Therefore, Shanghai's policymakers were first and foremost concerned with finding the most politically convenient way to enact the tax and prevent political discontent as much as possible. Shanghai therefore adopted a depoliticised approach to the tax, the logic of which was consistent with the conventional way in which the Chinese Government dealt with a host of thorny policy issues in the reform era, including the housing privatisation reform that Yu oversaw as the minister of housing and construction in the late 1990s.

More broadly speaking, the Chongqing Model threatened not only individual competitors in China's elite politics, but also the CCP's political establishment as a whole, as it sought to bring formidable popular energy to bear on high-level political competition. Once the masses were mobilised to actively participate in politics and embrace a particular political vision, no-one knew how much energy this would unleash, whether such energy would surge beyond anyone's control and develop a momentum of its own, or what disruption such energy would cause to the established political order. The Chongqing Model was indeed highly successful at mass mobilisation and building popular support for Bo Xilai, and this very success constituted a crisis for China's high-level politics. This fundamental tension underlined the dramatic and unexpected events in 2012 that marked the Chongqing Model's demise. Indeed, even after
Bo's downfall, the popular energy cultivated through years of mass mobilisation displayed a degree of resilience and could not be easily extinguished-as some in Chongqing even entertained the idea of 'saving' Bo by staging massive collective actions. This post-crisis situation loomed large as Xi Jinping took over the CCP leadership in 2012.

\section{Chongqing's Legacy in Xi Jinping's 'New Era'}

Despite its official demise in 2012, the Chongqing Model, it seems, has had a significant afterlife. Many of its mass-mobilisation techniques have since been incorporated into and enhanced by the CCP under Xi Jinping's leadership. On the one hand, the Chinese PartyState stepped up repression, surveillance, and the exercise of political coercion generally. On the other hand, it has become much more attentive to, and skilled at, mass political mobilisation than it was over the preceding two decades, as evidenced by, for example, how it mobilised youth and stemmed pro-regime sentiments through digital means. Similar to the Chongqing Model, the post-2012 political order features a mutually constitutive relationship between coercion and mobilisation: the masses are mobilised to celebrate the crackdown on dissident voices and some corrupt elites, as well as to strengthen this coercive apparatus by reporting to authority anything that looks politically suspicious.

Also similar to the Chongqing Model, today's state-led mass mobilisation is not a completely top-down project in which people passively receive what the state imposes on them. Instead, the success of this mobilisation hinges on the fact that people are shaped into political subjects who spontaneously engage in political activities expressing identity with the state. These subjects, sometimes derisively labelled the 'Little Pinks' (小粉红), derive a sense of agency and meaning from such political participation. Furthermore, in the post-2012 
political order, we also see a greater role being played by ideological messaging, more emphasis on a singular charismatic leader, and a much closer intertwining of political participation and everyday life-all of which seems to have been taken from Bo's playbook in Chongqing. Even though I can only speculate, there does seem to have been a deliberate learning process in which various mobilisation strategies that Bo pioneered or revived were copied and consolidated in Xi's 'New Era'.

At the same time, the elements of the Chongqing Model most threatening to the CCP's elite interests were dropped. Any tolerance of potentially contentious collective action, as displayed by Bo during the 2008 taxi drivers' strike, is now absent. Also gone is the aggressive ideological messaging around economic egalitarianism and anti-rich sentiments. If there is an ideology that holds today's mass-mobilisation project together, it is a pro-state ideology enmeshed in nationalist chauvinism.

Therefore, one could perhaps argue that the relationship between the Chongqing Model and the post-2012 political order under Xi's reign amounts to what Gramsci calls a 'passive revolution': when the political establishment faces a formidable challenge based on grassroots popular mobilisation, those trying to defend the establishment tend to not completely extinguish this challenging force. Instead, they selectively absorb and incorporate some elements of the insurrectionary challenge to make the status quo more resilient, while firmly rejecting those features that are most subversive and threatening.

This perspective makes it possible to understand the political transformations under Xi Jinping not as happenstance caused by one political leader, but the result of China's reform-era political history. It is important to recognise that the political order of the two decades after 1989 had a depoliticising face as well as a capitalistic one. On the one hand, the CCP tended to create widespread political apathy by framing both its policy actions and ordinary citizens as apolitical, similar to how Shanghai handled its tax on private homeownership. On the other hand, it pushed forward a set of structural changes in the economy that created a particularly brutal version of capitalism. Both of these faces gave rise to deep contradictions. The CCP's depoliticising tendency created a void in which people's underlying desire for meaningful political participation remained unfulfilled. At the same time, the version of capitalism it instituted engendered increasingly appalling economic inequality.

These contradictions were exactly what provided the exploitable openings for something like the Chongqing Model and enabled it to succeed in winning so much grassroots support. Combining mass mobilisation with egalitarian ideology, the Chongqing Model quickly garnered enough popular energy to appear threatening to the CCP's political establishment. Responding to this crisis, Xi's post-2012 regime had to selectively incorporate many elements of the Chongqing Model into its governing style. The political transformations under $\mathrm{Xi}$, therefore, were at least in part an indirect and unintended consequence of the depoliticising, capitalistic order that characterised the first two 'reform' decades after 1989. 
This text is taken from Made in China Journal: Volume 5, Issue 3, 2020, edited by Ivan Franceschini and Nicholas Loubere, published 2021 by ANU Press, The Australian National University, Canberra, Australia.

doi.org/10.22459/MIC.05.03.2020.03 